\title{
Relationship of Attitude and Achievement of Secondary School Students
}

\author{
Mr. Jubraj Khamari* Dr. Nibedita Guru** \\ * Deptt. Of School Of Education, MATS University, Arang, Raipur, (C.G) - INDIA \\ ** Deptt. Of Dr. RNIASE Cuttack, Uttkal University, Cuttack, Odisha - INDIA
}

\begin{abstract}
For quite understandable reasons and supportive empirical research evidences, it can be stated with brevity that, 'Education' has been considered and accepted as a very powerful instrument for development, growth and function of an individual in particular and that of the Nation in general. The level of education of an individual is undoubtedly determined, controlled, conditioned by certain non-cognitive factors in addition to the cognitive factors. Of these non-cognitive factors, the concept 'Attitude' has drawn the attention of many researchers and educationists for improvement of the academic performance of the children reading in secondary schools. There by attitude towards education, teacher, family and society influence academic achievement of the secondary school students. Hence the present study is going to be researched to that problem entitled "Relationship of Attitude and Achievement of Secondary School Students".
\end{abstract}

Keywords: Attitude towards education, Attitude towards family, Attitude towards society, Attitude towards teacher, Academic Achievement.

\section{Introduction}

As a concept, an attitude always refers to an individual's or group's more or less stable and observable tendency or predisposition to perform, perceive, think and feel in relation to something specific. Attitudes equip individuals or groups with a ready-made frame of reference in accordance with which they judge particular things.

Many psychologists have defined the word 'Attitude' in their own way. In simplest sense an attitude is a dispositional readiness to respond to certain situation, persons or objects on a consistent manner which has been learned and has become one's typical mode of response, an attitude has a well defined object of reference (s) in other words the generalized ways of behaving and viewing situation can be termed one's attitude.

On the basis of analysis of the available definitions of attitude. The main characteristics of attitude may be summarized as under.

1. The range of attitude in not limited.

2. The attitudes are the roots of the individual behavior.

3. The attitude is both covert and overt.

4. The attitude varies in direction as well as in the intensity or strength.

5. All attitudes of an individual are integrated in to an organized way.

6. Attitude is not inborn or innate but it is acquired. Therefore attitude differs from culture to culture.

7. The attitude is lasting and consistent but it can be modified.

The term 'Achievement' signifies accomplishment or gain or a performance carried out successfully by an individual on the completion of a task, be it academic, manual, personal and social. When Achievement is considered from academic point of view, it means the attained level at which the person is functioning in school tasks of different subjects measured through marks to rank the individuals in order of their achievement in the field of school achievement; better known as an Academic Achievement.

(a) Attitude:

\section{MEANING OF VARIABLES}

Attitude represents the way one feels, thinks, talks, or acts in a particular situation.

(b) Attitude towards Education:

The attitude of individuals towards education has been dealt with the degree of positive or negative effect associated with educational things like ideas, concepts, principles, laws and innovations etc.

(c) Attitude towards Teacher:

The attitude towards Teacher can be defined as the degree of positive or negatives effect associated with a student towards a teacher.

(d) Attitude towards Family:

The attitude towards family may be defined as the degrees positive or negative effect associated with family members, sympathy, affection etc. 
(e) Attitudes towards society:

The attitudes towards society are defined as the degree of positive or negative effect associated with the observation of social system, tradition, custom etc.

(f) Academic Achievement:

Academic Achievement implies one's knowledge, understanding or skills in a specified subject or group of subject areas.

\section{OBJECTIVES}

The main objectives of the study are the following:

1. To measure the attitudes of the students (pupils).

2. To measure the attitude towards Education, Teacher, Family and Society and their relationship with school achievement.

3. To measure the nature and degree of relationship between the various areas of "attitude" with "academic achievement."

\section{HYPOTHESES}

For the present study, the following hypotheses are formulated keeping the objectives in mind.

Ho1: The Ss with high and low achievement differ significantly on their scores and attitude.

Ho2: There will be significant difference between the high and low achievement in total Attitude and attitude towards teacher, education, family and society sub scores.

Ho3: The scores on attitude towards education, teacher, family and society have a high positive significant relationship with school achievement.

\section{SAMPLE}

110 students were selected from class IX of following two High School of Ambabhona Block of Bargarh District as noted below randomly:

1. Kedarnath Adivasi High School, Ambabhona, Bargarh, Odisha.

2. Purusottam High School, Ruchida, Bargarh, Odisha.

Who were divided into two groups on Median-split of their Achievement scores and were termed as High and Low Achievers respectively.

\section{TOOLS}

An attitude scale prepared by P.K. Panda which was translated to Oriya in 1990 from the original Hindi language and found to be more reliable and valid. That scale was used to measure the attitude of secondary school students towards-
(i) Education
(ii) Teacher
(iii) Family
(iv) Society

\section{Analysis And Interpretation Of Data}

Keeping in mind the various objectives of study, the collected data were analysed and interpreted with the help of statistical techniques in terms of 'Mean', Standard Deviation (SD), Co-efficient of Correlation and ' $t$ ' ration etc.

Table 1 : The Coefficient of Correlation 'r' of the Ss in High and Low Achievement

\begin{tabular}{|l|c|c|}
\hline \multicolumn{1}{|c|}{ Sample } & 'r' & 'p' \\
\hline $\begin{array}{l}\text { Total Ss } \\
(\mathrm{N}=100)\end{array}$ & 0.71 & $<0.01$ \\
\hline $\begin{array}{l}\text { High Achievers } \\
(\mathrm{N}=50)\end{array}$ & 0.46 & $<0.01$ \\
\hline $\begin{array}{l}\text { Low Achievers } \\
(\mathrm{N}=50)\end{array}$ & 0.50 & $<0.01$ \\
\hline
\end{tabular}

The Coefficient of Correlation values of the Ss between school achievement and attitude (tot) were calculated and presented in Table no. Lit is observed that all the V values of total, high and low achievement are highly significant. 
Table 2 : Mean and S. D's of Academic Achievement scores of the Ss

\begin{tabular}{|l|c|c|}
\hline \multicolumn{1}{|c|}{ M. } & Sample & S.D. \\
\hline $\begin{array}{l}\text { Total Ss. } \\
(\mathrm{N}=100)\end{array}$ & 275.29 & 114.70 \\
\hline $\begin{array}{l}\text { High Achievers } \\
(\mathrm{N}=50)\end{array}$ & 326.84 & 110.90 \\
\hline $\begin{array}{l}\text { Low Achievers } \\
(\mathrm{N}=50)\end{array}$ & 223.74 & 93.26 \\
\hline
\end{tabular}

The Mean and SD values on total School Achievement marks in Table - 2 reveal that the High achiever's mean score is greater than their counterparts. This confirms of our Hypothesis No 1 but to determine the level at which this difference is significant needs be tested in light of our hypothesis.

For this purpose the Critical Ratio (f) of the difference between Mean value scores have been computed and presented in table -2 .

Table -3 : The ' $t$ ' values of the Mean School Achievement scores between high and low achievers:

\begin{tabular}{|l|c|c|c|c|}
\hline \multicolumn{1}{|c|}{ Sample } & M. & S.D. & CR & 'P' \\
\hline $\begin{array}{l}\text { High Achievers } \\
(\mathrm{N}=50)\end{array}$ & 326.54 & 110.9 & \multirow{2}{*}{5.031} & $<.001$ \\
\hline $\begin{array}{l}\text { Low Achievers } \\
(\mathrm{N}=50)\end{array}$ & 223.74 & 93.26 & & \\
\hline
\end{tabular}

As proposed in previous interpretation, the ' $\mathrm{t}$ ' values between High and Low achievers on their total school Achievement scores have been computed and presented in Table - 3 above. The obtained ' $t$ ' value is 5.031 which is highly significant, $(\mathrm{P}<.001, \mathrm{df}=48)$. Thus the obtained ' $\mathrm{t}$ ' value confirms the Hypothesis No. 1 and as such the hypothesis is accepted.

Table No - 4 : M., SD's of Attitude scores of the Ss.

\begin{tabular}{|c|c|c|c|}
\hline Sources of Variation & Sample & M. & S.D. \\
\hline \multirow{3}{*}{ Total Attitude } & Total $(\mathrm{N}=100)$ & 35.69 & 23.46 \\
\hline & $\begin{array}{l}\text { High achievers } \\
(\mathrm{N}=50)\end{array}$ & 43.28 & 23.36 \\
\hline & $\begin{array}{l}\text { Low achievers } \\
(\mathrm{N}=50)\end{array}$ & 28.10 & 20.98 \\
\hline \multirow{3}{*}{ Attitude towards Education } & Total $(\mathrm{N}=100)$ & 9.11 & 7.96 \\
\hline & $\begin{array}{l}\text { High achievers } \\
(\mathrm{N}=50)\end{array}$ & 9.36 & 8.35 \\
\hline & $\begin{array}{l}\text { Low achievers } \\
(\mathrm{N}=50)\end{array}$ & 8.86 & 7.54 \\
\hline \multirow[b]{3}{*}{ Attitude towards Teacher } & Total $(\mathrm{N}=100)$ & 9.77 & 9.93 \\
\hline & High achievers $(\mathrm{N}=50)$ & 12.08 & 10.41 \\
\hline & $\begin{array}{l}\text { Low achievers } \\
(\mathrm{N}=50)\end{array}$ & 7.46 & 8.83 \\
\hline \multirow{3}{*}{ Attitude towards Family } & Total $(\mathrm{N}=100)$ & 14.42 & 10.75 \\
\hline & $\begin{array}{l}\text { High achievers } \\
(\mathrm{N}=50)\end{array}$ & 18.00 & 9.53 \\
\hline & $\begin{array}{l}\text { Low achievers } \\
(\mathrm{N}=50)\end{array}$ & 10.84 & 10.71 \\
\hline \multirow{3}{*}{ Attitude towards Society } & Total $(\mathrm{N}=100)$ & 2.39 & 7.44 \\
\hline & $\begin{array}{l}\text { High achievers } \\
(\mathrm{N}=50)\end{array}$ & 3.84 & 7.12 \\
\hline & $\begin{array}{l}\text { Low achievers } \\
(\mathrm{N}=50)\end{array}$ & 0.94 & 7.46 \\
\hline
\end{tabular}

The Mean and SD values of the Ss' on 'Attitude' scores \& sub scores have been computed and presented in table - 4. The Mean values of High achievers are greater than their counterpart in all the areas of attitude including Total Attitude. 
Moreover, the SD values also show more or less very close to one another bearing in few cases. In some areas, the Mean score of the high achievers are found to be greater than the corresponding value of total Ss. This has happened due to the procedure of scoring this scale as in the some case. The individual's scores have been negative as evident from the nature of the items and scoring procedure of the 'Attitude - scale' already described.

However, inference about the significance of the difference described above between the two experimental groups needs to be tested. This have been done and presented in table- 5 .

Table No - 5 : ' $t$ ' of Mean values on Attitude and its sub-scores between high and low achievers.

\begin{tabular}{|c|c|c|c|c|c|}
\hline Sources of Variation & Sample & M. & S.D. & 't' & 'p' \\
\hline \multirow[b]{2}{*}{ Total Attitude } & $\begin{array}{l}\text { High achievers (N } \\
=50)\end{array}$ & 43.28 & 23.36 & \multirow[b]{2}{*}{3.41} & \multirow[b]{2}{*}{$<.01$} \\
\hline & $\begin{array}{l}\text { Low achievers }(\mathrm{N} \\
=50)\end{array}$ & 28.10 & 20.98 & & \\
\hline \multirow[b]{2}{*}{ Attitude towards Education } & $\begin{array}{l}\text { High achievers }(\mathrm{N} \\
=50)\end{array}$ & 9.36 & 8.35 & \multirow[b]{2}{*}{0.314} & \multirow[b]{2}{*}{ N.S. } \\
\hline & $\begin{array}{l}\text { Low achievers }(\mathrm{N} \\
=50)\end{array}$ & 8.86 & 7.54 & & \\
\hline \multirow[b]{2}{*}{ Attitude towards Teacher } & $\begin{array}{l}\text { High achievers (N } \\
=50)\end{array}$ & 12.08 & 10.41 & \multirow[b]{2}{*}{2.39} & \multirow[b]{2}{*}{$<.05$} \\
\hline & $\begin{array}{l}\text { Low achievers (N } \\
=50)\end{array}$ & 7.46 & 8.83 & & \\
\hline \multirow[b]{2}{*}{ Attitude towards Family } & $\begin{array}{l}\text { High achievers }(\mathrm{N} \\
=50)\end{array}$ & 18.00 & 9.53 & \multirow[b]{2}{*}{3.53} & \multirow[b]{2}{*}{$<.01$} \\
\hline & $\begin{array}{l}\text { Low achievers (N } \\
=50)\end{array}$ & 10.84 & 10.71 & & \\
\hline \multirow[b]{2}{*}{ Attitude towards Society } & $\begin{array}{l}\text { High achievers }(\mathrm{N} \\
=50)\end{array}$ & 3.84 & 7.12 & \multirow[b]{2}{*}{1.99} & \multirow[b]{2}{*}{$<.05$} \\
\hline & $\begin{array}{l}\text { Low achievers }(\mathrm{N} \\
=50)\end{array}$ & 0.94 & 7.46 & & \\
\hline
\end{tabular}

The ' $t$ ' values of the total attitudes and its sub scores between Ss and with high and low achievement are presented in table -5 . The result lead to conclude that, the Ss with High \& Low achievement differ significantly in respect of their total Attitude $(t=3.41, \mathrm{p}<.01 \mathrm{df}=98$ Attitude towards Teacher towards tr. $(\mathrm{t}=2$. $39, \mathrm{p}<. \mathrm{o5}, \mathrm{df}-98)$, Attitude towards family $(\mathrm{t}=3.53, \mathrm{p}<.01, \mathrm{df}=98$ Attitude towards Society $(\mathrm{t}=1.99, \mathrm{p}<.01$ $\mathrm{df}=98)$ as such the hypothesis 2 is tenable.

It is interesting and equally note worthy too the two groups of Ss do not differ on their Attitude towards Education ( $\mathrm{t}=0.314, \mathrm{P}=\mathrm{NS}, \mathrm{df}=98$ ) The reasons of such a finding is quite obvious, possibly, due to the fact that the Ss irrespective of their achievements posses a positive attitude for receiving education, which is a very natural phenomena and tendency of human beings within the domain of differential abilities in academic performance.

Table - 6 : Coefficient of Correlation (' $r$ ') value between Attitude \& school achievement scores.

\begin{tabular}{|l|l|c|c|}
\hline \multicolumn{1}{|c|}{ Sources of variation } & \multicolumn{1}{c|}{ Sample } & 'r' & 'p' \\
\hline Attitude towards Education & $\begin{array}{l}\text { Total Ss } \\
(\mathrm{N}=100)\end{array}$ & .229 & $<.05$ \\
\hline Attitude towards Teacher & $\begin{array}{l}\text { Total Ss } \\
(\mathrm{N}=100)\end{array}$ & .440 & $<.01$ \\
\hline Attitude towards Family & $\begin{array}{l}\text { Total Ss } \\
(\mathrm{N}=100)\end{array}$ & .209 & $<.01$ \\
\hline Attitude towards Society & $\begin{array}{l}\text { Total Ss } \\
(\mathrm{N}=100)\end{array}$ & $\begin{array}{c}\text { (555 } \\
(\mathrm{N}=100)\end{array}$ & $<.05$ \\
\hline Total Attitude & \begin{tabular}{l} 
Total Ss \\
\hline
\end{tabular}
\end{tabular}

As proposed and hypothesized earlier the Coefficient of Correlation values of the various areas of attitude namely:-

i. Attitude towards education,

ii. Attitude towards Teachers,

iii. Attitude towards family, 
iv. Attitude towards society.

And the total attitude scores with Total School Achievement scores have been presented in Table-6. The computed values are all significant at $\mathrm{P}<.01$ expecting that of the Attitude towards Education which is significant at $\mathrm{P}<.05$ level. These results confirm our hypothesis -3 .

\section{FINDINGS}

1. The coefficient of correlation (r) of Ss between school achievement and attitude (tot) are highly significant. $(\mathrm{r}=0.71$ and $\mathrm{p}<.01)$.

2. The ' $t$ ' values of the Mean school achievement scores between high and low achievers is 5.031 which is significant at 0.001 .

3. The ' $t$ ' values on attitude scores between high and low Achievers is 3.41 which is significant at 0.01 levels.

4. The ' $r$ ' values between attitude and school achievement scores are significant.

\section{Conclusion}

1. High and Low achievers differ significantly in the academic achievement.

2. The attitudes of the High and Low achievers significantly different in the dimension of attitude towards teacher, society, and family. But towards education, there is no significant difference between them.

\section{Referance}

[1]. Allport G. W: 'Attitudes' in C Murchison (Ed), A Hand Book Of Social Psychology Worcesper, Mass: Clark University Press, 1935, 798-843.

[2]. Anastasi Anni: Psychological Testing, New York : Macmillan Company, 1964

[3]. Astana B and Agrawal R N: Measurement and Evaluation in Psychology and Education, Agra- 2; Vinod Pustak Mandir.

[4]. Best John W Prentice: Research in Education, New Delhi: Hall of India 1978.

[5]. Bhatnagar J K: The Values and Attitudes of Some Indian and British Students Race, 9(1) 27-3

[6]. Cronbach Lee J: Essentials of Psychological Testing, New York Harper and Row, (1970).

[7]. Ebel Robert L: "Must All Test be Valid" Am. Psychologists, October 1976, 640-647

[8]. Edward A L: Techniques of Attitude Scale Construction, Bombay; Vakils, Feffer \& Simson, 1969

[9]. Ervin F S: Sentence Completion Responses and Scholastic Success or Figure, Journal of Counseling Psychology, 1967, 14, 269271.

[10]. Garrett H E: Statistics in Psychology and Education, Indian Edition, Bombay Vakils, Feffer \& Simons Ltd. 1981.

[11]. Govil M: Changing Social Attitudes and Behavior Patterns among Post Graduate Students in U.P. Un Published Ph.D. Thesis, Agra University 1967

[12]. Guilford J P\& Frucher B: Fundamental Statistics in Psychology and Education. International Students Edition, New Delhi, lnc. 1978 .

[13]. Holland J. L: "The Prediction of College Grades from Personality \& Aptitude Variables", J Education Psychology, $1960,51$.

[14]. Manav R.N: Attitudes, Self concept, Values and Achievement of college Students, Anu Books, Shivaji Road, Meerut, 1988.

[15]. Mark M. H. and HillxW.A.: Systems and Theories in Psychology, New Delhi, Tata Me Graw Hill Publishing Co, 1973.

[16]. Mouly G.J: Psychology for Effective Teaching, H.O.H. Rinehart and Winston Inc. New York, 1973, 85-86.

[17]. Nason L. J: Academic Achievement of Gifted High School Students Loe Argeless, Calif University of Southern California Press, 1958.

[18]. Rao S.N: "Problems of Adjustment \& Academic Achievement” J voc. Edu. Quid., 1964. 10, 66-79

[19]. Rawat D.S: Measurement Evaluation and Stastics in education, New Delhi, New Raj Book Depot, 1970.

[20]. Simpson P.S: "The Relationship between attitudes towards reading and attitudes towards self as related 1978,38(10).

[21]. Solmon D: Parent Behaviour and Child Academic Achievement Achievement Striving and Related Personality Characteristics, Genetic Psychology Monographs, 1971, 83, 173-273.

[22]. Stanley J. C \& Porter A.C: "Correlation of Scholastic Aptitude test scores with College Grades for Nigroes vs Whites", Journal of Education, 1967, 4,199-218.

[23]. Sukhia S.P Mehrotra P V \& Mehrotra R.N.: Elements of Educational Research, Third Revised Edition, New Delhi, Allied Publisher Private Ltd. 1974.

[24]. Trafton B. F. "Relationship Between Self-concept, Learning Attitudes, Teacher Rating and Academic Achievement in Grades one to Eight", Diss. Abst. Inter, 1978, 38(10). 